\title{
Kendala Dalam Pembelajaran Jarak Jauh Pada Masa Pandemi Covid-19 (Studi Kasus di SDN Wanatirta 04 Kecamatan Paguyangan Kabupaten Brebes)
}

\author{
Maulia Azqia \\ SD Negeri Wanatirta 04 \\ liaseva29@gmail.com
}

\section{Article History}

received $3 / 12 / 2020$

\begin{abstract}
The Covid-19 pandemic that has hit the world, including Indonesia, requires taking a stand in preventing wider transmission, including the education sector. In this regard, the Ministry of Education and Culture has taken a firm stance through several circular letters relating to education policies in the emergency period of the spread of Covid-19. The distance learning process is a solution that is not yet optimal in its implementation. There are things that must be considered in this distance learning, among others, the quality of teacher resources must be improved, both in terms of content and methodology as well as in terms of the use of information technology. In addition, students are also less active in participating in this distance learning, both due to an unstable internet network and in terms of providing a limited internet quota. The purpose of writing this article is to study and understand the problems in learning activities during a pandemic, namely distance learning so that students can participate actively and interestingly. This study used a qualitative and observative approach. The results of this study prove that distance learning (PJJ) during the Covid-19 pandemic caused various responses and changes to the learning system that could affect the learning process and the level of development of students in responding to the material presented.
\end{abstract}

Keywords: Covid-19, distance learning, constraint, education

\begin{abstract}
Abstrak
Pandemi Covid-19 yang melanda dunia termasuk Indonesia mengharuskan mengambil sikap dalam mencegah penularan yang lebih luas, termasuk sektor pendidikan. Berkaitan dengan hal tersebut Kementerian Pendidikan dan Kebudayaan mengambil sikap tegas melalui beberapa surat edaran berkaitan tentang kebijakan pendidikan dalam masa darurat penyebaran Covid- 19 . Proses pembelajaran jarak jauh merupakan solusi yang dalam pelaksanaannya belum optimal secara keseluruhan. Ada hal yang harus diperhatikan dalam pembelajaran jarak jauh ini antara lain sumber daya guru harus ditingkatkan kualitasnya, baik dari segi konten maupun metodologi juga dalam hal pemanfaatan teknologi informasi. Selain itu, peserta didik juga kurang aktif dalam mengikuti pembelajaran jarak jauh ini, baik itu disebabkan jaringan internet yang kurang stabil maupun dari segi penyediaan kuota internet yang terbatas. Penelitian ini menggunakan pendekatan kualitatif dan observatif. Hasil kajian ini membuktikan bahwa pembelajaran jarak jauh (PJJ) di masa pandemi covid-19 ini menimbulkan berbagai tanggapan dan perubahan pada sistem belajar yang dapat mempengaruhi proses pemebelajaran serta tingkat perkembangan peserta didik dalam merespon materi yang disampaikan.
\end{abstract}

Kata kunci: Covid-19, pembelajaran jarak jauh, kendala, pendidikan $\begin{array}{ll}\begin{array}{l}\text { Social, Humanities, and Education Studies (SHEs): Conference Series } \\ \text { https://jurnal.uns.ac.id/shes }\end{array} & \text { e-ISSN 2620-9284 } \\ & 2620-9292\end{array}$ 


\section{PENDAHULUAN}

Pendidikan merupakan keseluruhan proses dimana seseorang mengembangkan kemampuan, sikap, dan bentuk-bentuk tingkah laku yang bernilai positif. Hal itu untuk menjalankan fungsi kemanusiaan yang diemban sebagai seorang hamba di hadapan Sang pencipta. Pendidikan sangat penting bagi kehidupan, bahkan tuntutan akan pentingnya pendidikan semakin besar mengingat arus perkembangan dunia yang semakin cepat. Pendidikan juga diartikan sebagai proses pembinaan dan bimbingan yang dilakukan seseorang secara terus menerus kepada anak didik untuk mencapai tujuan pendidikan (Bisri, 2013). Menurut Azra, pendidikan merupakan suatu proses penyiapan generasi muda untuk menjalankan kehidupan dan memenuhi tujuan hidupnya secara lebih efektif dan efisien (Azra, 2000).

Sejak munculnya wabah penyakit Corona atau disebut Covid-19 ke Indonesia pada bulan Maret 2020, Pemerintah Indonesia beserta Kementrian Pendidikan dan Kebudayaan memberlakukan diliburkan. Untuk mengurangi tersebarnya virus tersebut. Adanya pandemi Covid-19 yang melanda dunia termasuk Indonesia, berdampak pada berbagai aspek kehidupan salah satunya pendidikan. Maka lembaga pendidikan mengharuskan menjalankan proses kegiatan pembelajaran secara jarak jauh, yakni siswa belajar dan guru mengajar harus tetap berjalan meskipun peserta didik berada di rumah. Akibatnya, pendidik dituntut mendesain pembelajaran dengan memanfaatkan media daring (online). Hal Ini sesuai dengan keputusan Menteri Pendidikan dan Kebudayaan Republik Indonesia terkait Surat Edaran Nomor 4 Tahun 2020 tentang Pelaksanaan Kebijakan Pendidikan dalam Masa Darurat Penyebaran Covid-19. Berbagai inisiatif dilakukan untuk memastikan kegiatan belajar tetap berlangsung meskipun tidak adanya sesi tatap muka langsung. Teknologi, lebih spesifiknya internet, ponsel pintar, dan laptop sekarang digunakan secara luas untuk mendukung pembelajaran jarak jauh.

Pembelajaran Jarak Jauh (PJJ) adalah pembelajaran dengan menggunakan suatu media yang memungkinkan terjadi interaksi antara pengajar dan pembelajar. Pembelajaran jarak jauh (juga disebut juga pendidikan jarak jauh) merupakan pelatihan yang diberikan kepada peserta atau siswa yang tidak berkumpul bersama di satu tempat secara rutin untuk menerima pelajaran secara langsung dari instruktur. Bahan-bahan dan instruksi detail yang bersifat khusus dikirimkan atau disediakan untuk para peserta yang selanjutnya melaksanakan tugas-tugas yang akan dievaluasi oleh instruktur. Dalam kenyataannya dapat dimungkinkan instruktur dan peserta tersebut terpisah tidak hanya secara geografis namun juga waktu.

Pembelajaran jarak jauh telah menjadi tantangan bagi dunia pendidikan. Aspek penting dalam meningkatkan keterampilan pembelajaran jarak jauh harus ditingkatkan diantaranya dengan program pelatihan guru-guru dalam penggunaan teknologi informasi dan komunikasi. Untuk kelancaran dalam pembelajaran jarak jauh, guru tidak cukup hanya memiliki keterampilan teknologi dasar (seperti menggunakan komputer dan tersambung ke internet), tetapi juga pengetahuan untuk menggunakan perangkat rekaman dan perangkat lunaknya, serta metode untuk menyampaikan pelajaran tanpa interaksi tatap muka (video pembelajaran yang menarik). Keterampilan tersebut akan diperlukan ketika akan menggunakan platform belajar daring (online). Lebih penting lagi, kesenjangan antara skenario pelatihan dan eksekusi di lapangan perlu untuk diminimalisasi (Azzahra, 2020).

Proses pembelajaran jarak jauh (PJJ) selama masa pandemi covid-19 ini seharusnya tetap dapat mengakomodasi kebutuhan belajar siswa untuk mengembangkan bakat dan minat sesuai dengan jenjang pendidikannya. Namun untuk mewujudkan hal tersebut diperlukan kesiapan pendidik, kurikulum yang sesuai, ketersediaan sumber belajar, serta dukungan peranti dan jaringan yang stabil sehingga komunikasi antar peserta didik dan pendidik dapat efektif. Kondisi PJJ saat ini belum 
dapat disebut ideal sebab masih terdapat berbagai hambatan yang dihadapi. Kedua, banyak tugas merangkum dan menyalin dari buku. Ketiga, jam belajar masih kaku. Keempat, keterbatasan kuota untuk mengkuti pembelajaran daring. Dan kelima, sebagian siswa tidak mempunyai gadget pribadi sehingga kesulitan dalam mengikuti ujian daring.

Hambatan tersebut sekaligus menjadi tantangan dalam pelaksanaan PJJ mengingat pelaksanaan PJJ merupakan keharusan agar kegiatan pendidikan tetap dapat terselenggara di tengah darurat pandemi Covid-19 yang terjadi saat ini. Hambatan yang dihadapi dalam pelaksanaan PJJ antara lain berkaitan dengan kesiapan sumber daya manusia, kurang jelasnya arahan pemerintah daerah, belum adanya kurikulum yang tepat, dan keterbatasan sarana dan prasarana, khususnya dukungan teknologi dan jaringan internet. Kesiapan sumber daya manusia meliputi pendidik, peserta didik, dan dukungan orang tua merupakan bagian terpenting dalam pelaksanaan PJJ (Arifa, 2020).

Dalam rangka mencegah meluasnya penularan Covid-19 pada warga sekolah khususnya dan masyarakat luas pada umumya, Kementerian Pendidikan dan Kebudayaan (Kemendikbud) menerbitkan surat edaran terkait pencegahan dan penanganan Covid-19. Surat Edaran Nomor 4 Tahun 2020 tentang Pelaksanaan Kebijakan Pendidikan dalam Masa Darurat Penyebaran Corona virus Disease (Covid19) yang antara lain memuat arahan tentang proses belajar dari rumah melalui pembelajaran jarak jauh. Sekolah, di mana setiap hari terjadi aktivitas berkumpul dan berinteraksi antara guru dan siswa dapat menjadi sarana penyebaran Covid-19. Maka untuk melindungi warga sekolah dari paparan Covid-19, berbagai wilayah menetapkan kebijakan belajar dari rumah. Kebijakan tersebut menyasar seluruh jenjang pendidikan mulai dari jenjang prasekolah hingga pendidikan tinggi, baik negeri maupun swasta. Kebijakan belajar di rumah dilaksanakan dengan tetap melibatkan pendidik dan peserta didik melalui Pembelajaran Jarak Jauh (PJJ). Tulisan ini menjelaskan berbagai kendala pembelajaran jarak jauh (PJJ) yang dihadapi oleh guru, siswa maupun orang tua di SDN Wanatirta 04 dalam masa pandemi Covid-19.

\section{METODE}

Penelitian ini menggunakan penelitian kualitatif yang dilakukan untuk menggali, memahami, dan menggambarkan suatu obyek penelitian dengan cara deskriptif berupa kata kata dan bahasa (Moleong, 2002). Pendekatan penelitian bersifat kualitatif deskriptif (studi kasus), karena penelitian nanti akan menggambarkan atau melukiskan keadaan objek penelitian pada saat sekarang berdasarakan fakta-fakta yang sebagaimana adanya (Nawawi, 1996).

Metode penelitian ini adalah penelitian kualitatif, penelitian yang menghasilkan data deskriptif berupa kata-kata tertulis atau lisan dari orang-orang dan perilaku yang dapat diamati (Tanzeh, 2011). Peneliti sebagai instrumen kunci dan hasil penelitian lebih menekankan makna daripada generalisasi. Peneliti mengambil jenis penelitain ini dengan alasan untuk mendeskripsikan dan memaparkan data tentang kendala pembelajaran jarak jauh pada masa pandemi covid-19 pada jenjang Sekolah Dasar (SD). Jenis penelitian yang digunakan dalam penelitian ini adalah desain penelitian yang bersifat deskriptif kualitatif. Penelitian deskriptif kualitatif adalah rancangan penelitian yang menggambarkan data penelitian secara objektif.

Dalam penelitian ini, peneliti hanya menggambarkan atau mendeskripsikan kendala pembelajaran pembelajaran jarak jauh pada masa pandemi covid-19. Penerapan desain ini dilakukan dengan mengumpulkan data, mengelolah, dan menyajikan data secara objektif. Berdasarkan rumusan masalah, penelitian ini membahas mengenai kendala dalam pelaksanaan pembelajaran jarak jauh di SDN Wanatirta 04, Kecamatan Paguyangan Kabupaten Brebes. Sedangkan sumber data dari penelitian ini adalah:

1. Siswa kelas 2 SDN Wanatirta 04; dan 
2. Wali murid kelas 2 SDN Wanatirta 04.

Teknik pengumpulan data dalam penelitian ini ada tiga yakni teknik observasi, dokumentasi, dan wawancara. Berdasarkan teknik pengumpulan data yang digunakan, maka instrumen dalam penelitian ini adalah berhubungan dengan kendala-kendala pembelajaran jarak jauh pada masa pandemi covid-19 terutama di SDN Wanatirta 04. Instrumen penelitian yang dimaksud adalah a) observasi yang dilakukan secara online untuk mengamati keadaan secara tidak langsung dalam proses pelaksanaan pembelajaran dengan menggunakan Google Form; dan b) alat dan aplikasi pendukung (laptop, smartphone, google classroom, google formulir) yang digunakan untuk mendapatkan data berdasarkan teknik observasi dan/atau wawancara; dan c) berupa dokumen yang bersangkutan dengan pembelajaran yang diminta secara langsung kepada guru. Berdasarkan teknik pengumpulan data yang digunakan, maka instrumen dalam penelitian ini adalah berhubungan dengan kendala pembelajaran jarak jauh pada masa pendemi covid-19. Peneliti melakukan perpanjangan pengamatan dengan mengkaji kendala pada pembelajaran jarak jauh agar diperoleh data yang valid dan reliabel.

Penelitian ini dilaksanakan di SDN Wanatirta 04 yang terletak di Dukuh Krajan, Kecamatan Paguyangan, Kabupaten Brebes - Jawa Tengah. Objek penelitian adalah siswa kelas 2 dan Walimurid kelas 2 SDN Wanatirta 04. Penelitian ini dilakukan dengan mengidentifikasi permasalahan yang terjadi pada kegiatan pembelajaran di sekolah selama pandemi Covid-19. dengan pembelajaran secara daring. Situasi sosial yang menjadi dari penelitian ini adalah media pembelajaran daring, pendidik, dan peserta didik. Kemudian data dikumpulkan, dianalisis, dan disimpulkan sesuai kebutuhan yang mungkin dapat terjadi penyelesaian masalah tersebut berupa strategi pembelajaran jarak jauh yang menyenangkan selama masa pandemi Covid-19.

\section{HASIL DAN PEMBAHASAN}

Dalam proses pembelajaran, banyak kendala yang dihadapi oleh guru sebagai pendidik yang terbagi dalam beberapa indikator di antaranya: 1) proses penyampaian materi pembelajaran, 2) proses interaksi dengan siswa dalam proses pembelajaran, 3) kualitas pemberdayaan sarana dan elemen dalam pembelajaran, 4) mengelola bahan ajar untuk disampaikan dalam proses pembelajaran, dan 5) penyusunan perangkat Kurikulum yang sesuai dengan kondisi saat ini (Rezky, 2020).

Hasil temuan yang diperoleh dari penelitian ini adalah siswa yang kurang mampu memahami isi materi yang telah dipaparkan lewat media online oleh guru, jaringan internet yang terkadang terganggu, kurangnya penggunaan media pembelajaran secara online sehingga beberapa materi pelajaran yang membutuhkan alat dan/atau media pembelajaran tertentu tidak dapat tersampaikan oleh guru secara maksimal.

Untuk menyelesaikan masalah tersebut, pihak sekolah sudah berusaha mengatasi kendala tersebut seperti mengadakan pelatihan kepada para guru terkait penggunaan media pembelajaran secara online seperti penggunaan google classroom, google formulir, membuat video pembelajaran menggunakan Camtasia dan aplikasi inshoot pada handphone. Selain itu, sarana dan prasarana pendukung yang digunakan oleh guru dalam proses pembelajaran seperti penguatan jaringan internet sudah dibangun, sehingga proses pembelajaran jarak jauh (online) dapat terlaksana dengan maksimal.

Dalam hal sikap guru terhadap siswa dalam pembelajaran jarak jauh, ini terbagi dalam beberapa indikator di antaranya: 1) menyikapi atau mempersepsi karakter atau watak seorang guru terhadap proses pembelajaran, 2) menyikapi atau mempersepsi karakter atau watak seorang siswa terhadap proses pembelajaran, 3) membantu rasa percaya diri siswa dalam proses pembelajaran, dan 4) melakukan pembinaan kepada siswa dalam proses pembelajaran yang memiliki kendala dalam pembelajaran jarak jauh. 
Maka dari itu, seorang guru perlu mengetahui dan dapat menerapkan beberapa prinsip mengajar agar dapat melaksanakan tugasnya secara profesional. Diantaranya, (1) guru harus dapat membangkitkan perhatian peserta didik pada materi pelajaran yang diberikan serta dapat menggunakan berbagai media dan sumber belajar yang bervariasi; (2) guru harus dapat membangkitkan minat peserta didik untuk aktif dalam berpikir serta mencari dan menemukan sendiri pemecahan permasalahan yang dihadapi; (3) guru harus mengembangkan sikap peserta didik dalam membina hubungan sosial, baik itu sesama teman maupun terhadap lingkungan masyarakat; dan (4) guru harus menyelidiki dan mendalami perbedaan peserta secara individual agar dapat melayani peserta didik sesuai dengan kemampuannya.

Kondisi belajar siswa saat belajar di rumah sudah 9 bulan lamanya waktu yang cukup lama, sehingga membuatnya jenuh yang akhirnya bermalas-malasan. Guru merasa kesulitan dalam memberikan motivasi dalam proses pembelajaran karena siswa juga merasa tidak diawasi, apalagi kedua orang tuanya bekerja, sehingga tidak ada yang membimbingnya untuk belajar, sedangkan proses pembelajaran berlangsung di pagi sampai siang hari. Untuk mengukur hasil belajar siswa, ini kendala yang dialami guru karena sulitnya siswa dalam menangkap atau memahami setiap indikator yang disampaikan selama PJJ berlangsung, meskipun indikator-indikator pembelajaran telah berulang disampaikan oleh guru melalui media pembelajaran seperti google classroom. Siswa malah terkadang tidak membuka sama sekali google classroom, padahal semua materi dan penjelasan sudah disampaikan. Hal ini membuat guru merasa kesulitan untuk mengetahui apakah siswa tersebut sudah memahami apa yang disampaikan untuk mencapai Kriteria Kentuntasan Minimal (KKM) yang telah ditentukan sebelumnya.

Kenyataan yang terjadi di lapangan didukung dengan Permendikbud No. 65 Tahun 2013 terkait kegiatan pendahuluan, bahwa guru harus mempersiapkan hal-hal sebagai berikut: (1) mengondisikan siswa agar siap mengikuti proses pembelajaran; (2) memberikan motivasi belajar kepada siswa secara kontekstual sesuai manfaat dan aplikasi materi ajar dalam kehidupan sehari-hari; (3) mengajukan pertanyaanpertanyaan yang mengaitkan pengetahuan sebelumnya dengan materi yang akan dipelajari; (4) mengantarkan siswa kepada suatu permasalahan yang akan dilakukan untuk mempelajari suatu materi dan menjelaskan tujuan pembelajaran yang akan dicapai; dan (5) menyampaikan garis besar cakupan materi dan penjelasan tentang kegiatan yang akan dilakukan siswa untuk menyelesaikan permasalahan atau tugas. Guru harus pandai mengolah kelas, agar dapat menimbulkan suasana belajar yang kondusif, memberikan motivasi kepada siswa, perhatian, bahkan harus lebih membangun komunikasi dengan orang tua peserta didik mengenai perkembangan peserta didik selama di rumah (Kemdikbud, 2013).

Mengenai proses pembimbingan siswa, guru siap dihubungi kapan saja dalam hal mambantu siswa dalam memahami dan menyelesaikan tugas-tugasnya. Sedangkan dalam menyikapi proses belajar siswa, kendalanya adalah memberikan teguran kepada siswa yang tidak pernah aktif di google classrom, padahal cukup mengisi daftar hadir yang disediakan atau cukup berkomentar saja itu sudah dianggap hadir. Anggapan sebagian siswa bahwa dalam memberikan tugas tidak banyak yang mampu mengerjakannya dengan tepat berdasarkan dengan yang telah diajarkan, dalam hal ini siswa membutuhkan pendampingan secara langsung. Berdasarkan hasil daftar siswa secara online, mereka tidak mampu memanfaatkan waktu belajar dengan baik, cara belajar mereka tidak teratur sehingga mencerminkan siswa tersebut memiliki kebiasaan belajar yang tidak baik, hal itu terlihat ketika pengisian daftar hadir, kadang diisi sore atau di hari lain. Temuan ini berdasarkan hasil rekapan pengisian daftar hadir secara online, baik itu melalui google classroom atau google formulir. Seharusnya siswa dapat menunjukkan bahwa dirinya telah mampu memecahkan tugas-tugas belajar atau mentransfer hasil belajar. Akan tetapi, nyatanya di lapangan banyak siswa yang masih merasa kesulitan dalam hal ini. Solusinya adalah guru baiknya memberikan model 
pembelajaran yang bervariasi kepada siswa agar siswa tidak terbebani dan tidak merasa bosan dalam proses pembelajaran jarak jauh ini. Guru juga harus berusaha memberikan pengertian kepada siswa bahwa materi atau tugas yang diberikan sangatlah mudah.

Proses pembelajaran jarak jauh (PJJ) idealnya tetap dapat mengakomodasi kebutuhan belajar siswa untuk mengembangkan bakat dan minat sesuai dengan jenjang pendidikannya. Untuk mewujudkan hal tersebut diperlukan kesiapan pendidik, kurikulum yang sesuai, ketersediaan sumber belajar, serta dukungan peranti dan jaringan yang stabil sehingga komunikasi antar peserta didik dan pendidik dapat efektif. Kondisi PJJ saat ini belum dapat disebut ideal sebab masih terdapat berbagai hambatan yang dihadapi. Hambatan tersebut sekaligus menjadi tantangan dalam pelaksanaan PJJ mengingat pelaksanaan PJJ merupakan keharusan agar kegiatan pendidikan tetap dapat terselenggara di tengah darurat pandemi Covid-19 yang terjadi saat ini. Hambatan yang dihadapi sekaligus menjadi tantangan dalam pelaksanaan PJJ antara lain berkaitan dengan kesiapan sumber daya manusia, kurang jelasnya arahan pemerintah daerah, belum adanya kurikulum yang tepat, dan keterbatasan sarana dan prasarana, khususnya dukungan teknologi dan jaringan internet. Kesiapan sumber daya manusia meliputi pendidik, peserta didik, dan dukungan orang tua merupakan bagian terpenting dalam pelaksanaan PJJ.

Banyak keluhan baik dari pendidik, peserta didik, maupun orang tua terkait pelaksanaan pembelajaran jarak jauh. Sebagian pendidik mengeluhkan terbatasnya kemampuan pengoperasian media pembelajaran secara online maupun keterbatasan akses jaringan internet. Hal itu juga dirasakan oleh wali murid dan siswa ketika mengisi survei mengenai pelaksanaan pembelajaran jarak jauh. Masalah yang dihadapi tersebut berkaitan dengan: pertama, interaksi guru dan siswa pada saat pembelajaran berlangsung. Kedua, alokasi dana untuk pembelian kuota internet. Ketiga, ketertarikan siswa mengikuti pembelajaran jarak jauh.

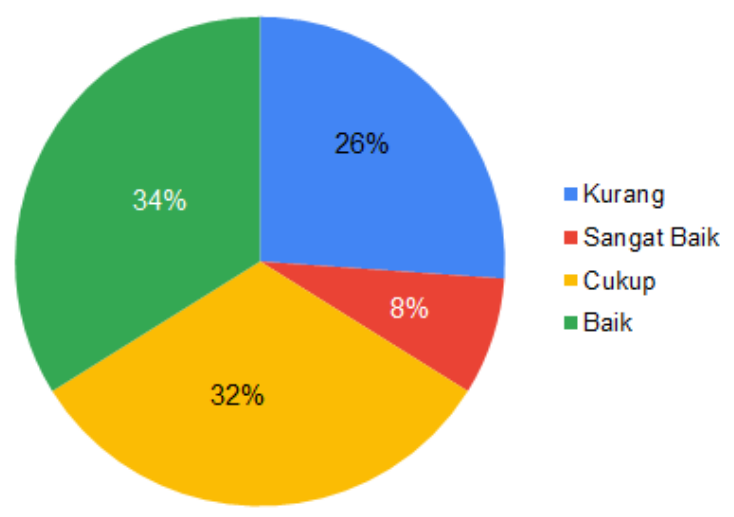

Gambar1.Respon peserta didik tentang interaksi guru dengan siswa saat PJJ 


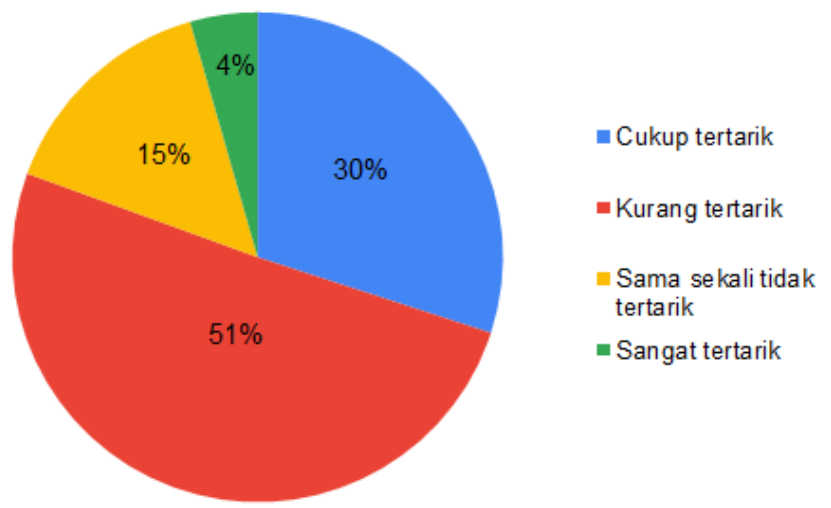

Gambar 2. Respon peserta didik tentang ketertarikan mengikuti PJJ

Berdasarkan gambar diagram di atas, sebagian besar siswa kelas 8 dari 180 responden dalam hal: pertama, interaksi guru dan siswa pada saat pembelajaran berlangsung hasilnya baik. Kedua, mengenai alokasi dana untuk pembelian kuota internet menghabiskan lebih dari 100.000 per bulan. Ketiga, ketertarikan siswa mengikuti pembelajaran jarak jauh hasilnya kurang tertarik. Saat ini, proses pendidikan terkait pembelajaran jarak jauh belum maksimal.

\section{Upaya Penanganan Masalah Proses Pembelajaran Jarak Jauh}

Dalam dunia pendidikan, internet dapat dijadikan sebuah pembelajaran. Pembelajaran ini berupa electronic learning atau yang dikenal dengan istilah e-learning (Munadi, 2010). Mengemukakan e-learning dapat diartikan sebagai jenis bahan pembelajaran yang memungkinkan tersampaikannya bahan ajar ke peserta didik dengan menggunakan media internet.

Dengan kemajuan teknologi informasi dan komunikasi saat ini, dapat mengantarkan dunia maya menjadi nyata berada di hadapan kita. Dunia tidak lagi dibatasi oleh jarak, ruang, dan waktu. Dengan demikian segala aktivitas akan lebih mudah dan cepat. Paradigma sistem pendidikan yang semula konvensional dengan mengandalkan tatap muka, maka dengan sentuhan teknologi informasi khususnya dunia cyber beralih menjadi sistem pendidikan jarak jauh yang tidak dibatasi oleh ruang, waktu, dan jarak, sehingga hubungan antara pembelajar dan pengajar bisa dilakukan kapan saja dan dimana saja (Munir, 2009).

Menanggapi berbagai keluhan terkait kendala akses internet maupun aktivitas belajar yang memberatkan pendidik maupun peserta didik, Kemendikbud mengimbau untuk mewujudkan pendidikan bermakna yang tidak hanya fokus pada capaian aspek akademik atau kognitif. Secara lebih jelas aturan mengenai proses belajar dari rumah diatur dalam Surat Edaran Mendikbud No. 4 Tahun 2020 tentang Pelaksanaan Kebijakan Pendidikan dalam Masa Darurat Penyebaran Coronavirus Disease (Covid2019). Poin 2 surat edaran tersebut menjelaskan proses belajar dari rumah dilaksanakan dengan ketentuan: pertama, dilaksanakan untuk memberikan pengalaman belajar yang bermakna bagi siswa, tanpa terbebani tuntutan menuntaskan seluruh capaian kurikulum untuk kenaikan kelas maupun kelulusan. Kedua, difokuskan pada pendidikan kecakapan hidup, antara lain mengenai pandemi Covid-19. Ketiga, aktivitas dan tugas pembelajaran dapat bervariasi antar siswa, sesuai minat dan kondisi masing-masing, termasuk mempertimbangkan kesenjangan akses/fasilitas belajar di rumah. Keempat, bukti atau produk aktivitas belajar dari rumah diberi umpan balik yang bersifat kualitatif dan berguna dari guru, tanpa diharuskan memberi skor/ nilai kuantitatif.

Guru diharapkan kreatif dan inovatif dalam mengeksplor kegiatan belajar yang menyenangkan, terutama karena keterbatasan teknologi dan koneksi internet. Sebagai 
contoh pembelajaran melalui projek pembuatan hand sanitizer berbahan rempah tradisional yang dapat langsung digunakan siswa.

Guru dalam konteks pendidikan mempunyai peranan yang besar dan strategis. Hal ini karena guru yang berada di barisan terdepan dalam pelaksanaan pendidikan. Sebagai praktisi, guru harus dituntut untuk menyelaraskan antara perubahan zaman yang ditandai dengan kecanggihan teknologi dengan nilai-nilai budi pekerti. Dengan begitu maka sekolah bisa menjadi benteng moral bagi anak-anak sehingga mereka dapat tumbuh beriringan dengan teknologi dan memanfaatkannya untuk hal-hal yang positif. Sebagai sebuah profesi, seorang guru wajib memiliki kualifikasi akademik, kompetensi, sertifikasi pendidik, sehat jasmani dan rohani, serta memiliki kemampuan untuk mewujudkan tujuan pendidikan nasional (UU No. 14 Tahun 2005).

Dalam hal meningkatkan pembelajaran jarak jauh, pemerintah mendukung dan memfasilitasi pelaksanaan pembelajaran daring lebih luas, bekerja sama dengan Kominfo dan provider layanan telekomunikasi. Berkat upaya tersebut masyarakat dapat mengakses beragam konten belajar jarak jauh melalui berbagai platform seperti Rumah Belajar, Kelas Pintar, Quipper School, Ruang Guru, dan Zenius untuk jenjang PAUD dan Dikdasmen. Sebagai bentuk dukungan, Pemerintah mendorong prioritas Rumah Belajar untuk dapat bekerja sama dengan Lembaga Penyiaran Publik (LPP) TVRI dan RRI agar sistem pembelajaran berbasis IT ini bisa dimanfaatkan saat kendala di jaringan internet.

\section{SIMPULAN}

Proses pembelajaran jarak jauh yang dilaksanakan saat ini belum dapat disebut sebagai kondisi belajar yang ideal, melainkan kondisi darurat yang harus dilaksanakan. Masih terdapat berbagai kendala sehingga semua pembelajaran dapat optimal. Pemerintah bekerja sama dengan berbagai pihak terkait melakukan berbagai upaya untuk dapat mengatasi permasalahan yang terjadi dalam PJJ, baik dari sisi regulasi, peningkatan kesiapan pendidik, serta perluasan jaringan dan akses sumber belajar, agar dapat berjalan secara efektif dan efisien. Namun demikian, upaya tersebut perlu terus ditingkatkan agar optimalisasi PJJ tidak hanya untuk kondisi darurat seperti saat ini tetapi juga untuk dilaksanakan dalam situasi normal sesuai dengan kebutuhan belajar. Pemerintah terus berupaya mendorong sinergitas berbagai sektor terkait agar upaya peningkatan kualitas pendidikan, baik dalam masa darurat Covid-19 maupun penyelenggaraan pendidikan keberlanjutan di masa depan dapat dioptimalkan.

\section{DAFTAR PUSTAKA}

Arifa, F.N. 2020. Tantangan Pelaksanaan Kebijakan Belajar Dari Rumah Dalam Masa Darurat Covid-19. Info Singkat, XII, No. 7/I/Puslit/April/2020.

Azra, A. 2000. Pendidikan Islam, Tradisi dan Modernisasi Menuju Milenium Baru, Cet. II. Jakarta: Logos.

Azzahra, N.F. 2020. Mengkaji Hambatan Pembelajaran Jarak Jauh di Indonesia di Masa Pandemi Covid-19. Jakarta: Center for Indonesian Policy Studies (CIPS).

Bisri, H. 2013. Landasan Pendidikan. Bandung: Pustaka Setia.

Hadari Nawawi, H. Murti Martini. 1996. Penelitian Terapan. Yogyakarta: Gajahmada University Press.

Kementerian Pendidikan dan Kebudayaan. 2013. Peraturan Menteri Pendidikan Dan Kebudayaan Republik Indonesia Nomor 65 Tahun 2013 Tentang Standar Proses Pendidikan Dasar Dan Menengah. Jakarta.

Moleong, Lexi J. 2011. Metode Penelitian Kualitatif. Bandung: Remaja Rosdakarya.

Munadi Y. 2010. Media Pembelajaran (Sebuah Pendekatan Baru). Jakarta: Gaung Persada Press.

Munir. 2009. Pembelajaran Jarak Jauh Berbasis Teknologi Informasi dan komunikasi. 